Modernizing Patriarchy 
THIS PAGE INTENTIONALLY LEFT BLANK 


\section{Modernizing Patriarchy}

The Politics of Women's

Rights in Morocco

KATJA そ̌VAN ELLIOTT

University of Texas Press 
Copyright (C) 2015 by the University of Texas Press

All rights reserved

Printed in the United States of America

First edition, 2015

Requests for permission to reproduce material from this work should be sent to:

Permissions

University of Texas Press

P.O. Box 7819

Austin, TX 78713-7819

http://utpress.utexas.edu/index.php/rp-form

All photographs courtesy of the author.

(a) The paper used in this book meets the minimum requirements of ANSI/NISO Z39.48-1992 (R1997) (Permanence of Paper).

\section{Library of Congress Cataloging-in-Publication Data}

Žvan Elliot, Katja, 1978-

Modernizing patriarchy : the politics of women's rights in Morocco /

Katja Žvan Elliott. - First edition.

pages $\mathrm{cm}$

ISBN 978-1-4773-0244-6 (cloth)

ISBN 978-1-4773-0245-3 (library e-book)

ISBN 978-1-4773-0246-0 (non-library e-book)

1. Women's rights-Morocco. 2. Feminism-Morocco. 3. WomenMorocco-Social conditions-21st century. I. Title.

HQ1236.5.M8Z83 2015

$305.4096409^{\prime} 05-\mathrm{dc} 23$

doi:10.7560/302446 
To my babi, mom, and sister. For they are amazing women. 
[H]ow can society achieve progress, while women, who represent half the nation, see their rights violated and suffer as a result of injustice, violence and marginalization, notwithstanding the dignity and justice granted them by our glorious religion?

- MINISTRY OF COMMUNICATION, 2003

Since acceding to the throne of his noble ancestors, His Majesty King Mubammad VI, our Chief Commander of the Faithful, may God protect him, has made the promotion of human rights a priority which lies at the very heart of the modernist democratic social project of which His Majesty is a leader. Doing justice to women, protecting children's rights and preserving men's dignity are a fundamental part of this project, which adheres to Islam's tolerant ends and objectives, notably justice, equality, solidarity, ijtihad [juridical reasoning] and receptiveness to the spirit of our modern era and the requirements of progress and development.

- PREAMble to THE 2004 FAMily CODE

His Majesty King Muhammad VI . . has insisted . . on making the Moroccan family - based upon shared responsibility, affection, equality, equity, amicable social relations and proper upbringing of children - a substantial major component of the democratization process, given that the family constitutes the essential nucleus of society.

- PREAMble to THE 2004 FAMily CODE

These provisions should not be regarded as flawless, nor should they be perceived from a fanatic angle. Instead, you should address them with realism and clearsightedness, keeping in mind that this is an ijtihad effort which is suitable for Morocco at this point in time, in its endeavors to achieve the development objective it is pursuing a wise, gradual, and determined manner.

- MINISTRY OF COMMUNICATION, 2003 